\title{
Pendekatan Nilai Logaritma dan Inversnya Secara Manual
}

\author{
Moh. Affaf \\ Program Studi Pendidikan Matematika, STKIP PGRI BANGKALAN \\ affafs.theorem@yahoo.com
}

\begin{abstract}
Abstrak-Pada pengaplikasiannya, banyak pengguna yang menggantungkan masalah perhitungan logaritma ataupun inversnya pada kalkulator scientific. Dalam makalah ini, akan diajukan sebuah metode untuk menghitung nilai logaritma beserta inversnya dengan cara manual, yaitu hanya dengan memanfaatkan operasi kali dan bagi. Dengan ini, diharapkan pengguna tidak lagi bergantung pada kalkulator scientific dalam menyelesaikan masalah perhitungan nilai logaritma beserta inversnya.
\end{abstract}

Kata kunci: logaritma, logaritma invers, metode numerik

\section{PENDAHULUAN}

Logaritma adalah salah satu studi dalam matematika yang baru mulai dipelajari saat tingkat pertama di kelas terakhir, yaitu pada tingkat pembelajar menengah pertama atau sederajat pada semester kedua tingkat akhir. Pada tingkat ini, pembelajar masih dikenalkan pada definisi logaritma serta beberapa penggunaan dasarnya. Dalam tingkat ini pula, pembelajar hanya dikenalkan tentang nilai logaritma untuk kasus istimewa saja.

Pada sekolah tingkat atas atau sederajat, para pembelajar akan dihadapi pada masalah yang membutuhkan perhitungan nilai logaritma maupun inversnya, baik itu studi tentang Matematika, Fisika, maupun Kimia. Hampir dalam semua permasalahan, jarang sekali melibatkan sudut-sudut istimewa. Dalam menghadapi hal ini, hampir seluruh pengguna menggantungkan masalah perhitungan ini pada kalkulator scientific. 
Dilain pihak, telah diketahui bahwa tidak ada nilai eksak secara numerik untuk beberapa sudut pada sinus dan cosinus serta beberapa nilai mantisapada basis tertentu [2]. Hal ini memberikan penjelasan bahwa nilai yang diberikan kalkulator untuk trigonometri dan logaritma merupakan suatu nilai pendekatan. Dengan kata lain, nilai pendekatan tersebut juga diperoleh melalui proses operasi biasa/ manual, yaitu hanya dengan menggunakan operasi tambah, kurang, kali, dan bagi. Oleh karena itu, Affaf [1] memberikan sebuah metode yang cukup mudah untuk menentukan nilai trigonometri atau inversnya, yaitu hanya dengan melihat nilai sudut atau arc yang diminta sebagai modifikasi dari metode Radhkrisnan [3]. Selain itu, Radhskrishnan [3] juga memberikan pendekatan nilai logaritma dengan metode yang sederhana, yaitu hanya dengan memanfaatkan beberapa rumus logaritma pada sekolah tingkat atas. Dalam metodenya ini, Radhsrisnan menggunakan dua operasi manual, yaitu operasikali dan bagi.

Untuk metode yang diajukan oleh Radhskrishnan, iterasi/proses yang dilakukan adalah 16 kali iterasi dengan taraf ketelitian sampai tiga angka dibelakan koma. Bagi peneliti, taraf ketelitian tersebut terlalu kecil untuk 16 iterasi. Dengan kata lain, peneliti merasa bahwa metode tersebut masih dapat diperbaiki sehingga iterasi yang dilakukan sesedikit mungkin.

Dari latar belakang yang telah disebutkan di atas, maka permasalahan yang diangkat dalam penelitian ini adalah memodifikasi metode Radhskrishnan sehingga iterasi yang dilakukan untuk mencapai ketelitian tiga angka dibelakang koma dapat diminimalkan. Dengan begitu, maka metode ini dapat digunakan pembelajar untuk menentukan nilai logaritma dan inversnya dan hanya memerlukan waktu yang relatif singkat.

\section{METODE PENELITIAN}

Seperti yang telah dijelaskan sebelumnya, penelitian ini bertujuan untuk menjelaskan kepada pembelajar bahwa semua nilai trigonometri maupun logaritma dan inversnya dalam kalkulator scientific merupakan nilai yang proses perhitungannya hanya memanfaatkan operasi yang sudah sangat mereka kenal selama ini, yaitu operasi tambah, kurang, kali, dan bagi. Oleh karena itu, dalam penelitian ini akan diajukan sebuah prosedur perhitungan nilai pendekatan 
logaritma dan inversnya. Dengan demikian, pembelajar dapat melihat bagaimana proses kerja kalkulator sehigga mendapatkan nilai pendekatan yang diinginkan. Selain itu, dengan prosedur ini, diharapkan pembelajar tidak bergantung lagi pada kalkulator scientific dalam menghitung atau menentukan nilai logaritma maupun inversnya dalam memecahkan masalah yang berkaitan dengan logaritma, seperti yang sudah dijelaskan dalam urgensi penelitian ini. Dengan kata lain, diharapkan pembelajar dapat menggunakan prosedur atau metode yang diajukan dalam penelitian ini dalam menghitung nilai logaritma maupun inversnya secara manual.

Pada 2008, Radhskrishnan memberikan metode yang sederhana dalam menentukan pendekatan nilai logaritma. Metode ini dikatakan sederhana karena hanya dengan memanfaatkan beberapa rumus logaritma pada sekolah tingkat atas. Dalam metodenya, Radhskrishnan hanya menggunakan operasi jumlah dan bagi. Untuk metode yang diajukan oleh Radhskrishnan, iterasi/proses yang dilakukan adalah 16 kali iterasi dengan taraf ketelitian sampai tiga angka dibelakan koma.

Adapun langkah-langkah dari metode Radhskrishnan dalam menentukan nilai pendekatan dari logaritma adalah sebagai berikut.

1. Misalkan akan ditentuan nilai dari $\log x$, maka terlebih dahulu ubahlah $x$ menjadi $y \times 10^{n}$ dengan $0<y<1$ untuk suatu bilangan bulat $n$

2. Tuliskan sebagai $y$ sebagai $y_{0}$. Selanjutnya, bentuklah barisan $y_{1}, y_{2}, y_{3}, \ldots, y_{16}$ dengan aturan $y_{m}=y_{m-1}^{2}$ untuk setiap $m=1,2,3, \ldots, 16$.

3. Ubahlah $y_{16}$ menjadi $\bar{y}_{16} \times 10^{t}$ dengan $0<\bar{y}_{16}<1$ untuk suatu bilangan bulat $t$.

4. Tuliskan $\bar{y}_{16}$ sebagai $10^{s}$. Selanjutnya, pilihlah sebarang nilai diantara 0 dan 1 untuk diberikan kepada $s$, Maka

$$
\log x=\frac{t+s}{2^{16}}+n
$$


Untuk menghitung nilai pendekatan trigonometri, Radhs memberikan langkah-langkah dari logaritmainversnya adalah sebagai berikut.

1. Misalkan akan ditentuan nilai dari $\log x$, maka terlebih dahulu ubahlah $x$ menjadi $\lfloor x\rfloor+y$ dengan $0<y<1$.

2. Hitunglah $y \times 2^{16}$. Tuliskan $y \times 2^{16}$ menjadi $\left\lfloor y \times 2^{16}\right\rfloor+n$ dengan $0<n<1$.

3. Ubahlah $10^{n}$ menjadi bilangan aslit dengan $0<t<10$ untuk suatu bilangan bulat $t$.

4. Misalkan Maka, nilai untuk antilog y diberikan oleh

$$
\log ^{-1} y=\sqrt[16]{10^{\left[y \times 2^{16}\right\rfloor} \times t}
$$

Seperti yang telah dijelaskan sebelumnya, penelitian ini bertujuan untuk menjelaskan kepada pembelajar bahwa semua nilai trigonometri maupun trigonometri invers dalam kalkulator scientific merupakan nilai yang proses perhitungannya hanya memanfaatkan operasi yang sudah sangat mereka kenal selama ini, yaitu operasi tambah, kurang, kali, dan bagi. Oleh karena itu, dalam penelitian ini akan diajukan sebuah prosedur perhitungan nilai pendekatan trigonometri dan inversnya. Dengan demikian, pembelajar dapat melihat bagaimana proses kerja kalkulator sehigga mendapatkan nilai pendekatan yang diinginkan. Selain itu, dengan prosedur ini, diharapkan pembelajar tidak bergantung lagi pada kalkulator scientific dalam menghitung atau menentukan nilai trigonometri maupun inversnya dalam memecahkan masalah yang berkaitan dengan trigonometri, seperti yang sudah dijelaskan dalam urgensi penelitian ini. Dengan kata lain, diharapkan pembelajar dapat menggunakan prosedur atau metode yang diajukan dalam penelitian ini dalam menghitung nilai trigonometri maupun inversnya secara manual.

Langkah yang dilakukan untuk membangun prosedur ini adalah dengan cara membentuk himpunan A, yaitu

$\{\log 1.5, \log 2, \log 2.5, \log 3, \log 3.5, \log 4, \log 4.5, \log 5\} \cup$ $\{\log 5.5, \log 6, \log 6.5, \log 7, \log 7.5, \log 8, \log 8,5, \log 9, \log 9.5\}$ 
untuk prosedur perhitungan nilai pendekatan trigonometri dan membentuk himpunan B, yaitu

$$
\{1.5,2,2.5,3,3.5,4,4.5,5,5.5,6,6.5,7,7.5,8,8.5,9,9.5\}
$$

untuk prosedur perhitungan nilai pendekatan trigonometri invers.

\section{HASIL DAN PEMBAHASAN}

Pada bagian ini akan dijelaskan perbaikan dari prosedur Radhs, baik dalam prosedur perhitungan nilai pendekatan trigonometri maupun dalam prosedur perhitungan nilai pendekatan trigonometri invers.Berikut ini adalah langkah perbaikan dari prosedur perhitungan nilai logaritma.

1. Misalkan akan ditentuan nilai dari $\log x$, maka terlebih dahulu ubahlah $x$ menjadi $y \times 10^{n}$ dengan $0<y<1$ untuk suatu bilangan bulat $n$

2. Tuliskan sebagai $y$ sebagai $y_{0}$. Selanjutnya, bentuklah barisan $y_{1}, y_{2}, y_{3}, \ldots, y_{16}$ dengan aturan $y_{m}=y_{m-1}^{2}$ untuk setiap $m=1,2,3, \ldots, 16$.

3. Ubahlah $y_{16}$ menjadi $\bar{y}_{16} \times 10^{t}$ dengan $a<\bar{y}_{16}<b$ dengan $a, b \in A$ tidak ada $c \in A$ sehingga $a<c<b$ untuk suatu bilangan bulat $t$.

4. Tuliskan $\bar{y}_{16}$ sebagai $10^{s}$. Selanjutnya, pilihlah sebarang nilai diantara 0 dan 1 untuk diberikan kepada $s$, Maka

$$
\log x=\frac{t+s}{2^{16}}+n
$$

Selanjutnya, untuk langkah perbaikan dari prosedur perhitungan nilai pendekatan logaritmainversnya adalah sebagai berikut.

1. Misalkan akan ditentuan nilai dari $\log x$, maka terlebih dahulu ubahlah $x$ menjadi $\lfloor x\rfloor+y$ dengan $0<y<1$.

2. Hitunglah $y \times 2^{16}$. Tuliskan $y \times 2^{16}$ menjadi $\left\lfloor y \times 2^{16}\right\rfloor+n$ dengan $0<n<1$.

3. Ubahlah $10^{n}$ menjadi $t$ dengan $a<t<b$ dengan $a, b \in B$ tidak ada $c \in B$ sehingga $a<c<b$ untuk $\log ^{-1} a<10^{t}<\log ^{-1} b$.

4. Misalkan Maka, nilai untuk antilog y diberikan oleh 


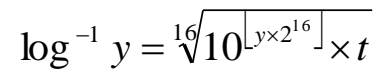

\section{Simpulan dan Saran}

Dari bab 3 di atas, dapat disimpulkan bahwa dengan cara memilih nilai pada langkah ketiga sebagai nilai dari trigonometri atau trigonometri invers rangkapnya, maka iterasi pada prosedur Radhs dapat dikurangi menjadi separuhnya. Meskipun demikian, tetap diperoleh taraf ketelitian yang sama, yaitu 0,0009 .

Untuk selanjutnya, penelitian ini dapat dilanjutkan. Permasalahan yang dapat diangkat salah satunya adalah mungkinkah mengurangi lagi iterasi yang lebih baik.

\section{Daftar Pustaka}

[1] Affaf, M. (2017, August 30). PERHITUNGAN NILAI PENDEKATAN TRIGONOMETRI DAN TRIGONOMETRI INVERS SECARA MANUAL. http://doi.org/10.17605/OSF.IO/M5R8T

[2] Herstein, I.R. 1996. Abstract Algebra. New York: John Wiley and Sons.

[3] Radhskrisnan, J. 2008. A Method for Finding trigonometric value and its inverse. India. 